\title{
A porcine model of complement activation-related pseudoallergy to nano-pharmaceuticals: Pros and cons of translation to a preclinical safety test
}

\author{
János Szebeni ${ }^{\mathrm{a}, 1,2,5}$, Péter Bedőcs ${ }^{3,4}$, László Dézsi ${ }^{1,2}$, Rudolf Urbanics ${ }^{1,2}$ \\ ${ }^{1}$ Nanomedicine Research and Education Center, Dept. of Pathophysiology, Semmelweis University, Budapest, \\ Hungary \\ ${ }^{2}$ SeroScience Ltd., Budapest, Hungary \\ ${ }^{3}$ Uniformed Services University of the Health Sciences, Bethesda, MD, USA ${ }^{b}$ \\ ${ }^{4}$ Henry M Jackson Foundation, Bethesda, MD, USA \\ ${ }^{5}$ Department of Nanobiotechnology and Regenerative Medicine, Faculty of Health, Miskolc University, Miskolc, \\ Hungary
}

Submitted: March 18, 2018

Accepted: April 27, 2018

Published: May 11, 2018

Abbreviations:

- API, active pharmaceutical ingredient

- $\mathrm{C}$, complement

- CARPA, C activation-related pseudoallergy

- HSR, hypersensitivity reaction

- MLV, large multilamellar liposomes

- NP, nanoparticle

- PAP, pulmonary arterial blood pressure

- PIM, Pulmonary intravascular macrophage

- $\quad$ SAP, systemic arterial blood pressure

\section{Abstract}

Pigs provide a sensitive and quantitative animal model of non-IgE-mediated (pseudoallergic) hypersensitivity reactions (HSRs) caused by liposomes and many other nanoparticulate drugs or drugcarrier nanosystems (nanomedicines). The rapidly arising symptoms, including cardiopulmonary, hemodynamic, hematological, blood chemistry and skin changes, resemble the clinical picture in man undergoing infusion reactions to reactogenic nanoparticles. In addition to summarizing the basic features of the pig CARPA model, the review considers some of the advantages and disadvantages of using the model for preclinical evaluation of nanomedicine safety $\mathrm{i}^{\mathrm{ii}}$.

\section{Keywords:}

Hypersensitivity reactions, complement, anaphylatoxins, animal models, hemodynamic changes, anaphylaxis, macrophages, mast cells, thromboxane.

${ }^{a}$ Corresponding Author. E-mail: jszebeni2@gmail.com, Nanomedicine Research and Education Center, Semmelweis University, 1089 Nagyvárad tér 4, Budapest, Hungary.

${ }^{\mathrm{b}}$ The views expressed in this manuscript are those of the authors and do not reflect the official policy of the Uniformed Services University, Departments of the Army, Navy or Air Force, Department of Defense, Department of Veterans Affairs, or the United States Government. 


\section{Rationale and Purpose}

Nanotechnology has achieved remarkable success in improving the therapeutic index of numerous drugs and agents by using drug-carrier nanosystems (nanocarriers) that carry and, in some cases, target the active pharmaceutical ingredient (API) to its site of action and/or control its absorption, distribution, metabolism, and excretion properties. However, together with these advantageous features, nanoparticulate (non-biological) complex drugs can cause adverse effects that the API alone would not cause. One of such adverse effects is a hypersensitivity reaction (HSR) which may occur typically at the first time of application. These acute and reversible immune reactions, also known as infusion-, or anaphylactic /anaphylactoid-, or idiosyncratic reactions, are not mediated by IgE. Due to this fact, they are commonly called "pseudoallergy," although the European Academy for Allergology and Clinical Immunology suggested to abandon this name (1). Nevertheless, we keep using it partly because it is notable, and partly because no appropriate alternative term was proposed for this type of HSR.

There is a large amount of direct and indirect evidence for the involvement of complement (C) activation in these pseudoallergies, which has led us to call this phenomenon $\mathrm{C}$ activation-related pseudoallergy (CARPA) (2). As detailed in previous studies and reviews (3-7), CARPA has been increasingly recognized as a possibly important mechanism of many unpredictable, poorly understood, severe, life-threatening HSRs to various intravenous (IV) drugs and agents, which still arise from time to time despite extensive anti-allergic pre-medications of patients and increasing alertness at the bedside for any sign of HSR. Most recently, HSRs to ironcontaining drugs have been associated with CARPA, at least in some of the patients $(8,9)$.

CARPA was first described in pigs (2), and ever since, pigs have been used as the best animal model to study this phenomenon (3-7). The goals of the present review are to outline the scientific background and essential features, advantages and disadvantages of the model and to provide an update about its use for the prediction of HSRs in man.

\section{Summary of relevant literature}

The $\mathrm{C}$ system is a phylogenetically ancient, essential part of the immune system consisting of some 30 proteins in serum and cell membranes (10). It represents the humoral arm of innate immunity with several physiological functions, among which first-line antimicrobial defense is the best known. Importantly for us, it has been recognized a long time ago that $\mathrm{C}$ activation, i.e., cascadic proteolysis of serum components leading to the formation of anaphylatoxins and other biologically active cleavage products, may play a role in HSRs as well (11). Since liposomes have been known to activate $\mathrm{C}$ for nearly half a century (12), association of $\mathrm{C}$ activation with HSRs in pigs appeared self-evident when liposome-induced anaphylaxis started to draw attention as a model of drug-induced HSRs (2, 13). Over the past 50 years we learned that liposomes and other NPs can activate $\mathrm{C}$ via all known activation pathways, such as classical, alternative and lectin (14-16), although these mechanisms may overlap and even switch, depending on the surface properties of NPs (17). In addition to the physicochemical properties, binding of plasma proteins also plays a significant role in $\mathrm{C}$ activation by NPs. This process was described as dynamic and reversible $(18,19)$, lending substantial variation to $\mathrm{C} 3$ deposition on NPs in different individuals under different conditions (20).

As for the mechanism of $\mathrm{C}$ activation in pigs, the binding of natural IgG and IgM antibodies to reactogenic liposomes points to classical pathway activation $(2,21,22)$. On the other hand, the massive hemodynamic effects of alternative pathway activators zymosan and carboxylated polystyrene NP (PS-NPs) (23) indicate a main role of alternative pathway activation.

Regardless of the particular biochemical pathway of $\mathrm{C}$ activation, the HSRs observed in pigs share many symptoms of human HSR reactions, most importantly the cardiovascular distress, which in extreme cases may even be lethal in patients. This critical relevance for safety, together with the sensitivity and reproducibility of the model enabling the analysis of minor amounts of drugs in relatively few animals, motivated several "porcine CARPA" studies over the past 20 years to explore the 
reactogenicity of a broad range of NPs and to better understand the mechanisms of these reactions $(13,2,24-33)$.

\section{Discussion}

\section{Technical aspects of the model}

Figure 1 illustrates the setup of the model with the different measurements and instruments applied. In brief, adolescent pigs (3-4 months old, 25-30 kg) are initially sedated, then anesthetized and undergo endotracheal intubation and catheterization of the pulmonary artery and the femoral artery to measure the pulmonary arterial pressure (PAP), systemic arterial pressure (SAP), and heart rate (HR). The introduction of tested materials and taking of blood samples are performed via venous catheters. The PAP, SAP and HR are monitored and recorded continuously, as well as the EKG and respiratory parameters (respiratory rate, $\mathrm{RR}$ ) and end-tidal $\mathrm{CO}_{2}\left(\mathrm{EtCO}_{2}\right)$.

\section{The symptoms of porcine CARPA and their human relevance}

Just as in humans, the symptoms of an HSR in pigs arise within minutes after intravenous adminstration of reactogenic NPs (reactive NPs) and the reactions subside within 15-60 min, depending on severity. Figure 2 illustrates the typical symptoms of severe HSRs in pigs with transient, but major hemodynamic, respiratory and skin changes (28). In this example, after the larger bolus dose of the reaction trigger intravenous lipid emulsion (ILE), the PAP steeply rose to maximal value and the animal stopped breathing spontaneously, controlled ventilation was initiated, and the RR fell to the rate of the respirator and the end-tidal $\mathrm{CO}_{2}$ dropped, indicating reduced pulmonary perfusion with decreased cardiac output, which are typical of shock. At the same time the plasma $\mathrm{TxB}_{2}$ level rose 30-fold over baseline and the animal displayed flushing and rash (inserts). After about 10 minutes all values started to return to normal.

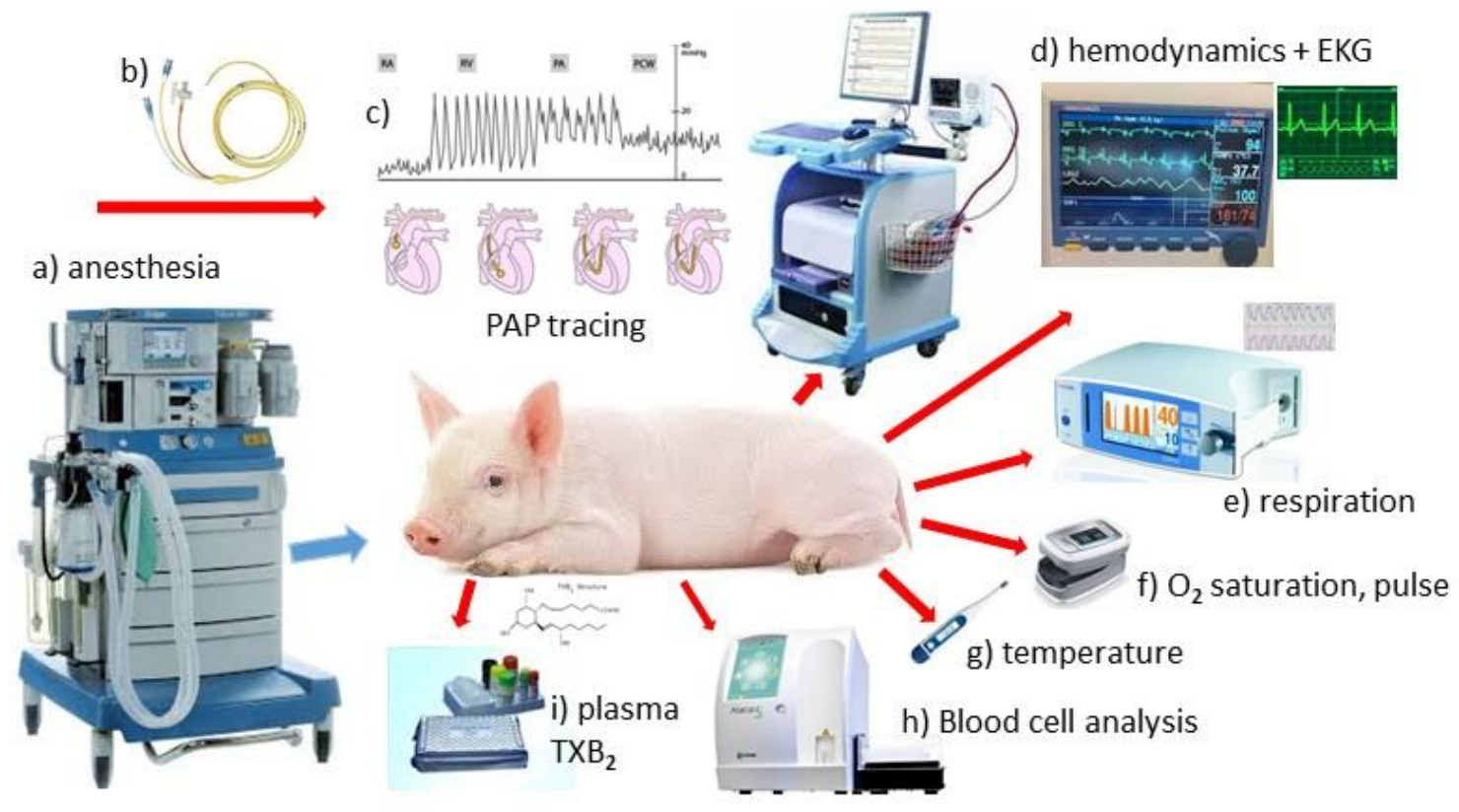

Figure 1. Parameters measured, and equipment used in the porcine CARPA model. a) anesthesia machine; b) Swan-Ganz balloon catheter, used for the measurement of pulmonary arterial pressure; c) blood pressure wave forms during passage of the tip of the Swan-Ganz catheter via the right atrium, right ventricle, and pulmonary artery until being wedged into the pulmonary capillary bed, d) computerized hemodynamic monitoring system tracing the systemic and pulmonary pressures, heart rate, and the EKG; e) capnograph measuring the respiratory rate (RR) and end-tidal carbon-dioxide (EtCO2; f) pulse oximeter measuring oxygen saturation and pulse rate; g) rectal temperature probe; h) blood cell analyzer; i) Enzyme Linked Immunosorbent Assay for measuring plasma mediators, such as TXB2. The figure was reproduced from Ref. (7) with permission. 


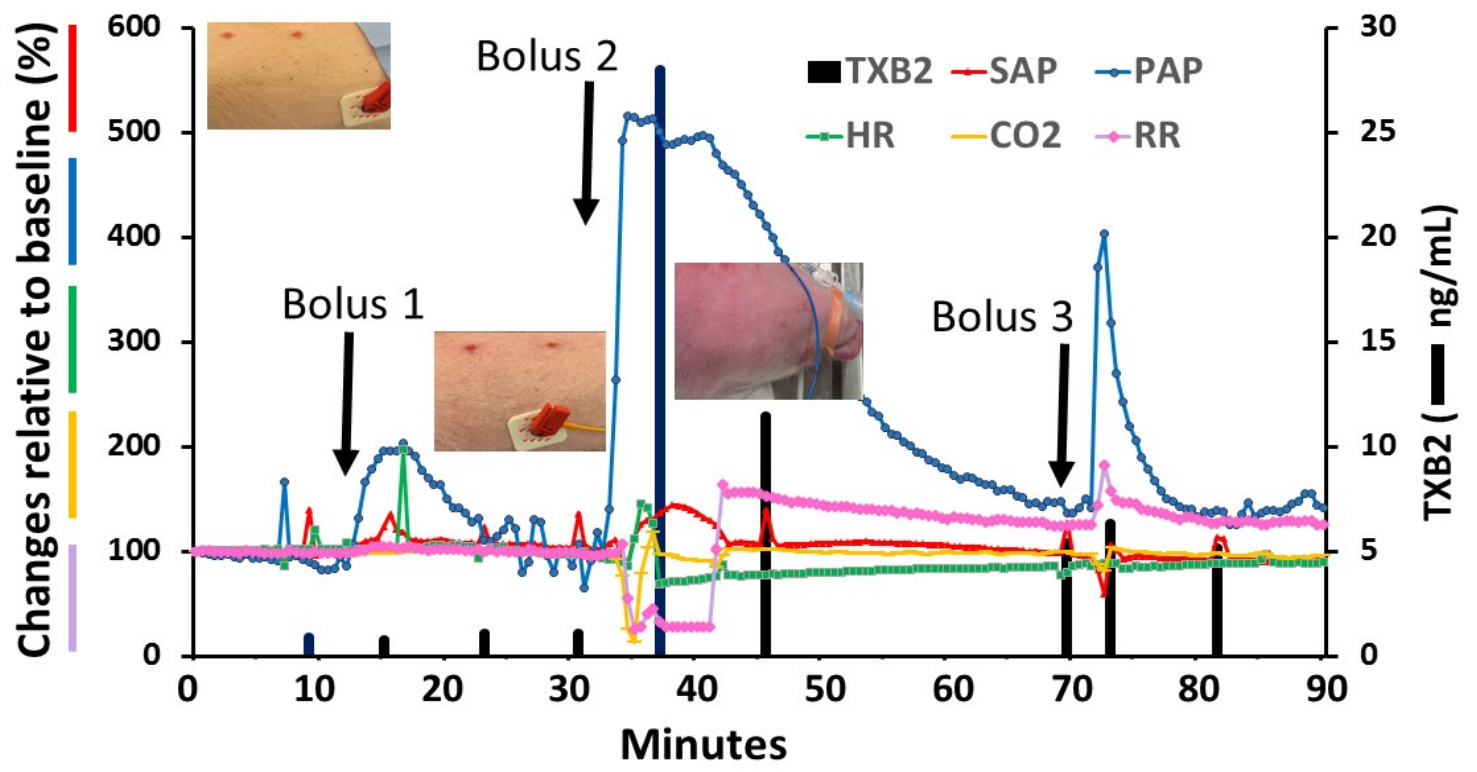

Figure 2. Hypersensitivity reaction of a pig to intravenous (IV) treatment with an IV lipid emulsion (Intralipid 20\%, ILE) and zymosan. The arrow shows the timing of IV injections: Bolus 1: $1.5 \mathrm{~mL} / \mathrm{kg}$ ILE; Bolus 2: $5 \mathrm{~mL} / \mathrm{kg}$ ILE; Bolus 3: $0.1 \mathrm{mg} / \mathrm{kg}$ zymosan. The figure was constructed from published (28) and unpublished data. The inserted skin photos are positioned according to the time of their capture. $\mathrm{CO} 2,=$ end-tidal $\mathrm{CO} 2$.

Figure $3 \mathrm{~A}$ illustrates yet another universal symptom of pig HSR to nanoparticles: transient blood cell changes. Typically, the white blood cells (WBC) and platelets (PLT) drop immediately after the injection of the reactogenic test substance and then return to baseline in about 15 minutes, while the WBC may later rise over baseline (not shown in Fig 3A), a reflection of overcompensation. The WBC changes include changes of granulocytes (Gr) and lymphocytes (Ly) in variable ratios. The most severe reactions in pigs, rapidly progressing into shock (Figure 3B), resemble the cardiovascular collapse underlying the lethal anaphylaxis in man.

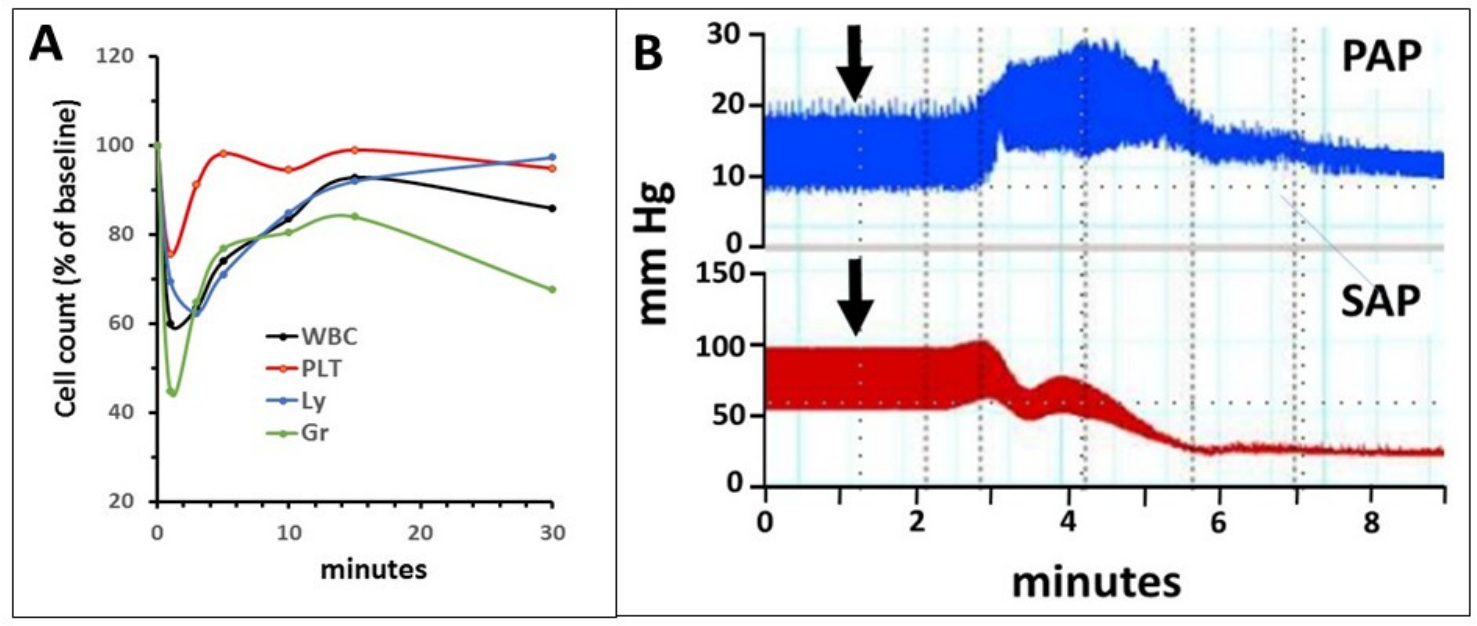

Figure 3. Blood cell changes and shock in severe HSR caused by liposomes in a pig. The arrow shows the timing of intravenous injection of PEGylated liposomal doxorubicin (Doxil, $0.1 \mathrm{mg} / \mathrm{kg}$ phospholipid), followed by cardiovascular collapse within 4-5 minutes. Real-time recordings of $A)$ pulmonary arterial pressure (PAP) and B) systemic arterial pressure $(S A P)$. Gr $=$ granulocytes; $L y=$ lymphocytes; $P L T=$ platelets; $W B C=$ white blood cells 
In addition to reproducing the severe, lifethreatening cardiovascular symptoms and skin alterations, what makes the pig model relevant to human HSRs is that the dose eliciting the reaction is identical or very similar to the doses that trigger life-threatening reactions in man. This statement is based on calculations that the bolus dose of PEGylated liposomal doxorubicin (Doxil) triggering pulmonary hypertension in pigs is identical to the amount of Doxil reaching the circulation of reactive patients within the first minutes of infusion, when the symptoms start (34). Although similar calculations have not been made for other reactive NPs, the reactogenic dose of phospholipid-containing reactive NPs is in the $0.01-0.1 \mathrm{mg} / \mathrm{kg}$ range on phospholipid weight/pig weight basis, a value that may guide similar calculations for other liposomal drugs. In rats and mice hemodynamic changes are triggered only by doses that are orders of magnitude higher (35).

\section{Hemodynamic alterations and their}

\section{mechanism}

Focusing on the initial hemodynamic changes and their likely mechanism, the transient, but significant rise of PAP is the most reproducible measure of adverse immunocirculatory response to reactogenic NPs, which we quantify as the primary endpoint of HSRs. Interestingly, while the PAP almost always rises, the extent and direction of changes of SAP are highly variable. The HR usually increases, or it does not change, while the most intense reactions may entail paradoxical bradycardia (26).

The pulmonary hypertension is most likely due to the release of TxA2, a known pulmonary vasoconstrictor eicosanoid. This assumption is supported by the remarkable parallelism between the rises of PAP and TxB2, the stable metabolite of $\mathrm{TxA}_{2}$ (Figure 2), and the observation that indomethacin, a cyclooxygenase blocker of $\mathrm{TxA}_{2}$ release, inhibits both processes $(2,32)$.

As for the source of $\mathrm{TxA}_{2}$, the primary suspects are pulmonary intravascular macrophages (PIM cells), which are resident macrophages adhered to the endothelium of pulmonary capillaries. The abundant presence of PIMs is observed only in a few species, such as sheep, cattle, horse, and cat (36). Their function is to screen the blood from particulate pathogens
(37-41). PIM cells express anaphylatoxin C5a receptor (ATR, C5aR) on their surface as well as Fc, Toll like- and $\mathrm{C}$ receptors (CR1, CR3 and CR4), and can secrete vasoactive mediators including $\mathrm{TxA}_{2}$, histamine, leukotrienes, PAF, and IL-6, IL- 8 and IL-1 $\beta$ ). The combination of different vasoactivity of all secretion products explains the versatility of systemic blood pressure changes in CARPA (40). However, TxA 2 and many of these mediators may also be released by other ATR+ cells, including mast cells, leukocytes and activated platelets (42). The relative contribution of these cells to $\mathrm{TxA}_{2}$ production in pig CARPA is not yet clarified.

The key role of macrophages in the cardiopulmonary distress of pigs following reactogenic NP administration was supported by a recent study showing close parallelism of the time courses of pulmonary hypertension caused by spherical polystyrene NPs (PS-NPs), their clearance from blood in mice and their uptake by cultured macrophages (32). Although the rapid phagocytosis of PS-NPs by PIM cells was suggested to be the main mechanism of the pigs' pulmonary response independent of $\mathrm{C}$ activation $(32,41)$, a follow-up review (43) and a recent study (23) argued against premature exclusion of the role of $\mathrm{C}$. It was pointed out that the in vitro ELISA results conducted in whole blood (32) could not provide adequate evidence for the absence of $\mathrm{C}$ activation in vivo, so the question needs to be further studied. In doing so, we found that other methodical approaches, namely FACS analysis of NP-coated C fragments (C5b-9 and $\mathrm{iC} 3 \mathrm{~b}$ ) and Western blot detection of $\mathrm{C} 3$ degradation did indicate $\mathrm{C}$ activation in pig serum by PS-NPs in vitro (23). Since the detected iC3b, $\mathrm{C} 3 \mathrm{~d}$, and $\mathrm{C} 3 \mathrm{dg}$ are known opsonins, and opsonization is a well-known trigger for enhanced phagocytic uptake (44-46), it is very likely that $\mathrm{C}$ activation played a role in the rapid clearance and "robust" uptake of PS-NPs by macrophages (32) via its opsonic ability. Whether or not opsonization of NPs by $\mathrm{C} 3 \mathrm{~b}$ and its byproducts is "complemented" by concurrent $\mathrm{C} 3 \mathrm{a} / \mathrm{C} 5 \mathrm{a}$ production and stimulation of cells via anaphylatoxin receptors is not yet clear. In any case, these data emphasize the complexity of CARPA, and the existence of two or more activation mechanisms (“double hit") $(5,27)$ 
rather than rapid phagocytosis representing an alternative mechanism of HSRs, competing with the CARPA concept $(32,41)$. On top of advancing this academic debate, the latter study (23) highlighted that $500 \mathrm{~nm}$ PS-NPs are the most potent inducers of HSR in pigs studied to date, possibly due to their high negative surface charge and hydrophobicity. Also, despite the difficulties in projecting in vitro $\mathrm{C}$ assay data to in vivo physiological changes (43), the study showed significant correlation between $\mathrm{C}$ activation by different sized PS-NPs in human serum and pulmonary hypertensive effect in pigs providing strong support for the CARPA background of PSNP reactions.

\section{Use of the pig model for safety screening}

The European Medicines Agency's latest guidance on generic liposome development (47) recommends "the use of in vitro and in vivo immune reactogenicity assays such as complement (and/or macrophage/basophil activation assays) and testing for complement activation-related pseudoallergy (CARPA) in sensitive animal model to evaluate the extent of potential adverse event". Accordingly, in vitro C assays and the porcine CARPA model have been increasingly applied for preclinical safety screening of nanodrug or contrast agent candidates. Recent examples of using these tests for safety assessment include the studies on nitroglycerin-loaded shear-responsive liposomes (30) and dextran-coated superparamagnetic iron oxide nanoparticles (SPIONs) developed for magnetic resonance imaging (MRI) $(31,48)$.

A recent study suggested association between the pulmonary hypertensive effect in pigs and historic data on HSRs in man following IV use of the MRI agents Sinerem ${ }^{\circledR}$ and Resovist ${ }^{\circledR}$. These are SPIONs and Sinerem, which was reactive in pigs, had been withdrawn from the market because of HSRs (33).

The pig model may be uniquely applicable for the prediction of HSRs due to the fact that the most sensitive endpoint of HSRs, the rise of PAP, is also the most reproducible physiological response to reactive NP exposure. This reproducibility is demonstrated in Table 1 , showing the inter-experimental variation of pulmonary hypertensive responses to (first) bolus administration of reactogenic liposomal nanomedicines and zymosan.

Table 1. Pulmonary Hypertensive Effects of Complement Activators: Data Collected From " $n$ " Different Experiments Performed Over $>6$ Years. Reproduced from (7) with permission.

\begin{tabular}{|l|c|l|}
\hline & $\begin{array}{c}1^{\text {st }} \text { PAP change } \\
(\% \text { of baseline })+/- \text { SEM }\end{array}$ & $\mathrm{n}$ \\
\hline Zymosan & $368,9 \pm 57,32$ & 15 \\
\hline Ambisome & $236,81 \pm 100,91$ & 7 \\
\hline Doxil & $233,11 \pm 91,79$ & 12 \\
\hline
\end{tabular}

Similar analysis performed on the changes of PAP in pigs injected with multilamellar liposomes (MLV) for the first time gave a $79 \pm 9$ $\%$ increase (mean \pm SEM, $n=18$ ) (2). Likewise, injection of the same MLVs in one animal 8 times over 8 hours led to a remarkably small $(2.56 \%)$ coefficient of variation of PAP (199 $\pm 0.5 \%$, mean $\pm \operatorname{SEM}(2)$.

\section{Ambiguities of the porcine model: the} sensitivity issue and tachyphylaxis

Despite the above-mentioned advantages, the use of pigs for preclinical testing of the safety of NPs has been questioned for the same reason that lends uniqueness to the model: its high sensitivity $(41,49)$. The reaction rate to most reactogenic NPs is practically $100 \%$ in pigs, while in men the incidence of most HSRs to reactive NPs is in the $1-10 \%$ range. This implies that the porcine test has large bias to false positivity. However, because of the PIM cells, pigs may be perceived as animals with born hypersensitivity, and, hence, the model is a disease model and not that of normal human responses to NP exposure. To our best knowledge, no rodent, or any other large animal model would serve this purpose, i.e. enabling experimentation on a small number of animals and getting statistically valid information on possible side effects and their prevention. If the model had the same incidence rate of reactions as in humans, hundreds of pigs would be needed to obtain statistically evaluable numbers of reactive animals.

Another unique property of the pig model is tachyphylaxis, i.e., self-induced tolerance arising to certain reactogenic NPs after repetitive 
administration. Typically, the reactions caused by PEGylated liposomes are tachyphylactic (27), while those caused by multilamellar DMPGcontaining liposomes (2), or AmBisome (50), are not. This implies that when testing tachyphylactic drugs, only the first administration will reflect the response of a hypersensitive individual, the rest of the injections will underestimate the drug's reactivity. In contrast, if the agent is nontachyphylactic, the model enables quantitation of multiple injections over hours, enabling doseeffect relationship and inhibition studies in individual animals.

\section{Theories on mechanism}

The mechanism underlying CARPA, in general, and tachyphylaxis, in particular, are poorly understood. The "double hit" theory (5, $27,40)$ mentioned above in the context of PIM cells, postulates that NPs can induce HSRs by simultaneous stimulation of anaphylatoxin receptors (mainly $\mathrm{C} 5 \mathrm{aR}, \mathrm{CD} 88$ ) and other surface receptors on PIM cells, which can be linked to release reactions directly or indirectly. Potential receptors include pathogen recognition receptors, also known as pathogen-associated molecular pattern receptors $(51,52)$, mannose-binding lectin receptor $(53,54), \mathrm{C}$ receptors (CR2 and CR3 and Fc receptors) (55) and many others typically present on the surface of mast cells $(56,57)$. Among these, the human Mas-related G-proteincoupled receptor member X2 (MRGPRX2) was claimed to be crucial for pseudoallergic drug reactions $(56,58)$.

These different activation pathways are likely to lead to different degrees of stimulation, and exhaustion of one or more pathways upon repetitive exposures might explain tachyphylaxis. It also follows from the above "multiple hit" concept that if one or the other activation pathway is sufficiently strong, or dominates, they alone might trigger the release reaction. For example, in case of very strong $\mathrm{C}$ activation, the C5aR (or $\mathrm{C} 3 \mathrm{aR}$ )-mediated anaphylatoxin "pathway" might dominate, while direct stimulants of mast cells, such as by opioids, neuromuscular blocking agents, quinolones, compound 48/80 (56), or physical stimuli of cold and trauma (59) might induce pseudoallergy directly, without C activation. Such reactions can be referred as Cindependent pseudoallergies (CIPA) (43).

\section{Conclusions}

The mechanism of HSR reactions to nanomedicines is poorly understood at this time, and the porcine CARPA model may help disentangle a very complex chain of immuno-hemodynamic changes. A unique feature of the model is that the most sensitive endpoint of HSRs, the rise of PAP, is also the most constant and reproducible physiological response, and it is a direct predictor of the most dangerous consequence of these reactions: anaphylactic shock. Regarding the mechanism of HSRs in this model, we believe the "double hit hypothesis" (5), advanced to "multiple hit hypothesis" (43), represents a more comprehensive explanation of these reactions than the recently proposed "rapid phagocytosis response" hypothesis (41), as it reconciles C-dependent and C-independent immune activations as simultaneous, independent, yet highly coordinated pathways of a complex activation cascade. The key role of secretory macrophages, such as PIM cells, is important to keep in mind, to inspire novel approaches for the prediction and prevention of HSRs (32). Because of its high sensitivity, the porcine CARPA model may serve as an efficient preclinical safety screening test for reactogenicity of NP-based drugs and other agents. However, the data obtained in this model should not be directly extrapolated to man. When considered to be a disease model in healthy animals, the concerns about false positive results are no longer relevant.

\section{Acknowledgment}

The authors acknowledge the supports by the European Union Seventh Framework Program grants NMP2012-309820 (NanoAthero), NMP-2013-602923 (TheraGlio) and the Applied Materials and Nanotechnology Center of Excellence' at Miskolc University, Hungary.

\section{Conflict of interest}

The authors have no relevant financial or non-financial interests to disclose. For signed statements contact the journal office editor@precisionnanomedicine.com. 
Quote this article as Szebeni J, Bedőcs P, Dézsi L, Urbanics R. A porcine model of complement activationrelated pseudoallergy to nano-pharmaceuticals: Pros and cons of translation to a preclinical safety test. Precis. Nanomed. 2018;1(1):63-73, https://doi.org/10.29016/180427.1

\section{References}

1. Johansson SG, Hourihane JO, Bousquet J, Bruijnzeel-Koomen C, Dreborg S, Haahtela T, et al. A revised nomenclature for allergy. An EAACI position statement from the EAACI nomenclature task force. Allergy. 2001;56(9):813-24.

2. Szebeni J, Fontana JL, Wassef NM, Mongan PD, Morse DS, Dobbins DE, et al. Hemodynamic changes induced by liposomes and liposome-encapsulated hemoglobin in pigs: a model for pseudoallergic cardiopulmonary reactions to liposomes. Role of complement and inhibition by soluble CR1 and anti-C5a antibody. Circulation. 1999;99(17):2302-9.

3. Szebeni J. Complement activation-related pseudoallergy: a new class of drug-induced acute immune toxicity. Toxicology. 2005;216(2-3):106-21.

4. Szebeni J, Muggia F, Gabizon A, Barenholz Y. Activation of complement by therapeutic liposomes and other lipid excipient-based therapeutic products: prediction and prevention. Advanced Drug Delivery Reviews. 2011;63(12):1020-30.

5. Szebeni J, Bedocs P, Csukas D, Rosivall L, Bunger R, Urbanics R. A porcine model of complementmediated infusion reactions to drug carrier nanosystems and other medicines. Advanced Drug Delivery Reviews. 2012;64(15):1706-16.

6. Szebeni J. Complement activation-related pseudoallergy: A stress reaction in blood triggered by nanomedicines and biologicals. Mol Immunol. 2014;61:163-73.

7. Urbanics R, Bedőcs P, Szebeni J. Lessons learned from the porcine CARPA model: constant and variable responses to different nanomedicines and administration protocols. Eur J Nanomedicine. 2015;7:219-31.

8. Hempel JC, Poppelaars F, Gaya da Costa M, Franssen CF, de Vlaam TP, Daha MR, et al. Distinct in vitro Complement Activation by Various Intravenous Iron Preparations. Am J Nephrol. 2017;45(1):49-59.

9. Macdougall IC, Vernon K. Complement Activation-Related pseudo-Allergy: A fresh look at hypersensitivity reactions to intravenous iron. Am J Nephrol. 2017;45(1):60-2.

10. Nesargikar PN, Spiller B, Chavez R. The complement system: history, pathways, cascade and inhibitors. European Journal of Microbiology \& Immunology. 2012;2(2):103-11.

11. Hugli TE, Stimler NP, Gerard C, Moon KE. Possible role of serum anaphylatoxins in hypersensitivity reactions. International archives of allergy and applied immunology. 1981;66 Suppl 1:113-20.

12. Alving CR, Kinsky SC, Haxby JA, Kinsky CB. Antibody binding and complement fixation by a liposomal model membrane. Biochemistry. 1969;8:1582-7.

13. Szebeni J, Fontana J, Wassef N, Mongan P, Morse D, Stahl G, et al. Liposome-induced and complementmediated cardiopulmonary distress in pigs as a model of pseudo-allergic reactions to liposomal drugs. Molecular Immunology. 1998;35(6):401.

14. Chonn A, Cullis PR, Devine DV. The role of surface charge in the activation of the classical and alternative pathways of complement by liposomes. Journal of immunology. 1991;146:4234-41.

15. Richards RL, Habbersett RC, Scher I, Janoff AS, Schieren HP, Mayer LD, et al. Influence of vesicle size on complement-dependent immune damage to liposomes. Biochimica et Biophysica acta. 1986;855(2):223-30.

16. Banda NK, Mehta G, Chao Y, Wang G, Inturi S, Fossati-Jimack L, et al. Mechanisms of complement activation by dextran-coated superparamagnetic iron oxide (SPIO) nanoworms in mouse versus human serum. Particle and fibre toxicology. 2014;11:64.

17. Hamad I, Al-Hanbali O, Hunter AC, Rutt KJ, Andresen TL, Moghimi SM. Distinct polymer architecture mediates switching of complement activation pathways at the nanosphere-serum interface: implications for stealth nanoparticle engineering. ACS Nano. 2010;4:6629-38.

18. Chen F, Wang G, Griffin JI, Brenneman B, Banda NK, Holers VM, et al. Complement proteins bind to nanoparticle protein corona and undergo dynamic exchange in vivo. Nature Nanotechnology. 2017;12(4):387-93.

19. Moghimi SM, Simberg D. Complement activation turnover on surfaces of nanoparticles. Nano Today. 2017;15:8-10. 
20. Benasutti H, Wang G, Vu VP, Scheinman R, Groman E, Saba L, et al. Variability of complement response toward preclinical and clinical nanocarriers in the general population. Bioconjugate Chemistry. 2017;28(11):2747-55.

21. Szebeni J, Wassef NM, Rudolph AS, Alving CR. Complement activation in human serum by liposomeencapsulated hemoglobin: the role of natural anti-phospholipid antibodies. Biochimica et Biophysica acta. 1996;1285:127-30.

22. Szebeni J, Wassef N, Hartman K, Rudolph A, Alving C. Complement activation in vitro by the red cell substitute, liposome-encapsulated hemoglobin: mechanism of activation and inhibition by soluble complement receptor type 1. Transfusion. 1997;37(2):150-9.

23. Mészáros T, Kozma G, Shimizu T, Miyahara K, Turjeman K, Ishida T, et al. Involvement of complement activation in the pulmonary vasoactivity of polystyrene nanoparticles in pigs: Unique surface properties underlying alternative pathway activation and instant opsonization. Int. J. Nanomed. 2018; Accepted (in press).

24. Szebeni J, Baranyi L, Savay S, Bodo M, Morse DS, Basta M, et al. Liposome-induced pulmonary hypertension: properties and mechanism of a complement-mediated pseudoallergic reaction. Am. J. Physiol 2000;279(3):H1319-28.

25. Bodo M, Szebeni J, Baranyi L, Savay S, Pearce F, Alving C, et al. Rheoencephalographic evidence of complement activation-related cerebrovascular changes in pigs. Journal of Cerebral Blood Flow and Metabolism. 2005;25:S550-S.

26. Szebeni J, Baranyi L, Savay S, Bodo M, Milosevits J, Alving CR, et al. Complement activation-related cardiac anaphylaxis in pigs: role of $\mathrm{C} 5 \mathrm{a}$ anaphylatoxin and adenosine in liposome-induced abnormalities in ECG and heart function. Am J Physiol Heart Circ Physiol. 2006;290(3):H1050-8.

27. Szebeni J, Bedocs P, Urbanics R, Bunger R, Rosivall L, Toth M, et al. Prevention of infusion reactions to PEGylated liposomal doxorubicin via tachyphylaxis induction by placebo vesicles: a porcine model. Journal of Controlled Release. 2012;160(2):382-7.

28. Bedocs P, Capacchione J, Potts L, Chugani R, Weiszhar Z, Szebeni J, et al. Hypersensitivity reactions to intravenous lipid emulsion in swine: relevance for lipid resuscitation studies. Anesth Analg. 2014;119(5):1094-101.

29. Jackman JA, Meszaros T, Fulop T, Urbanics R, Szebeni J, Cho NJ. Comparison of complement activationrelated pseudoallergy in miniature and domestic pigs: foundation of a validatable immune toxicity model. Nanomedicine, NBM. 2016;12(4):933-43.

30. Buscema M, Matviykiv S, Meszaros T, Gerganova G, Weinberger A, Mettal U, et al. Immunological response to nitroglycerin-loaded shear-responsive liposomes in vitro and in vivo. Journal of controlled release. 2017;264:14-23.

31. Unterweger H, Janko C, Schwarz M, Dezsi L, Urbanics R, Matuszak J, et al. Non-immunogenic dextrancoated superparamagnetic iron oxide nanoparticles: a biocompatible, size-tunable contrast agent for magnetic resonance imaging. International Journal of Nanomedicine. 2017;12:5223-38.

32. Wibroe PP, Anselmo AC, Nilsson PH, Sarode A, Gupta V, Urbanics R, et al. Bypassing adverse injection reactions to nanoparticles through shape modification and attachment to erythrocytes. Nature Nanotechnology. 2017;12:589-94.

33. Fulop T, Nemes R, Meszaros T, Urbanics R, Kok RJ, Jackman JA, et al. Complement activation in vitro and reactogenicity of low-molecular weight dextran-coated SPIONs in the pig CARPA model correlation with physicochemical features and clinical information. Journal of Controlled Release 2018;270:268-274.

34. Szebeni J, Baranyi B, Savay S, Lutz LU, Jelezarova E, Bunger R, et al. The role of complement activation in hypersensitivity to pegylated liposomal doxorubicin (Doxil®). J Liposome Res. 2000;10:347-61.

35. Dezsi L, Fulop T, Meszaros T, Szenasi G, Urbanics R, Vazsonyi C, et al. Features of complement activation-related pseudoallergy to liposomes with different surface charge and PEGylation: comparison of the porcine and rat responses. Journal of Controlled Release. 2014;195:2-10.

36. Brain JD, Molina RM, DeCamp MM, Warner AE. Pulmonary intravascular macrophages: their contribution to the mononuclear phagocyte system in 13 species. Am J Physiol 1999;276:146-54.

37. Dehring DJ, Steinberg SM, Wismar BL, Lowery BD, Carey LC, Cloutier CT. Complement depletion in a porcine model of septic acute respiratory disease. J Trauma. 1987;27(6):615-25. 
38. Dehring DJ, Fader RC, Traber LD, Traber DL. Cardiopulmonary changes occurring with pulmonary intravascular clearance of live bacteria in sheep. Circ Shock. 1989;29(3):245-56.

39. Dehring DJ, Lubbesmeyer HJ, Fader RC, Traber LD, Traber DL. Exaggerated cardiopulmonary response after bacteremia in sheep with week-old thermal injury. Crit Care Med. 1993;21(6):888-93.

40. Csukas D, Urbanics R, Weber G, Rosivall L, Szebeni J. Pulmonary intravascular macrophages: prime suspects as cellular mediators of porcine CARPA. Eur J Nanomed. 2015;7:27-36.

41. Moghimi SM. Nanomedicine safety in preclinical and clinical development: focus on idiosyncratic injection/infusion reactions. Drug Discovery Today. 2017. 2017; S1359-6446(17)30466-X. doi: 10.1016/j.drudis.2017.11.006

42. Patkó Z, Szebeni J. Blood cell changes in complement activation-related pseudoallergy. European J Nanomedicine. 2015;7:233-44.

43. Szebeni J. Mechanism of nanoparticle-induced hypersensitivity in pigs: complement or not complement? Drug Discovery Today. 2018. 2018;23:487-492.

44. Newman SL, Mikus LK. Deposition of C3b and iC3b onto particulate activators of the human complement system. Quantitation with monoclonal antibodies to human C3. The Journal of experimental medicine. 1985;161(6):1414-31.

45. Verbovetski I, Bychkov H, Trahtemberg U, Shapira I, Hareuveni M, Ben-Tal O, et al. Opsonization of apoptotic cells by autologous iC3b facilitates clearance by immature dendritic cells, down-regulates DR and CD86, and up-regulates CC chemokine receptor 7. The Journal of Experimental Medicine. 2002;196(12):1553-61.

46. Cunnion KM, Hair PS, Buescher ES. Cleavage of complement C3b to iC3b on the surface of Staphylococcus aureus is mediated by serum complement factor I. Infection and immunity. 2004;72(5):2858-63.

47. European Medicine Agency Reflection paper on the data requirements for intravenous liposomal products developed with reference to an innovator liposomal product. EMA/CHMP/806058/2009/Rev 02. 2013;www.ema.europa.eu/docs/en_GB/document.../WC500140351.pdf.

48. Matuszak J, Baumgartner J, Zaloga J, Juenet M, da Silva AE, Franke D, et al. Nanoparticles for intravascular applications: physicochemical characterization and cytotoxicity testing. Nanomedicine (Lond). 2016;11(6):597-616.

49. Skotland T. Injection of nanoparticles into cloven-hoof animals: Asking for trouble. Theranostics. 2017;7(19):4877-8.

50. Szebeni J, Bedocs P, Rozsnyay Z, Weiszhar Z, Urbanics R, Rosivall L, et al. Liposome-induced complement activation and related cardiopulmonary distress in pigs: factors promoting reactogenicity of Doxil and AmBisome. Nanomedicine : nanotechnology, biology, and medicine. 2012;8(2):176-84.

51. Arancibia SA, Beltran CJ, Aguirre IM, Silva P, Peralta AL, Malinarich F, et al. Toll-like receptors are key participants in innate immune responses. Biological research. 2007;40(2):97-112.

52. Akira S, Uematsu S, Takeuchi O. Pathogen recognition and innate immunity. Cell. 2006;124(4):783-801.

53. Fraser IP, Koziel H, Ezekowitz RA. The serum mannose-binding protein and the macrophage mannose receptor are pattern recognition molecules that link innate and adaptive immunity. Seminars in Immunology. 1998;10(5):363-72.

54. Tenner AJ, Robinson SL, Ezekowitz RA. Mannose binding protein (MBP) enhances mononuclear phagocyte function via a receptor that contains the $126,000 \mathrm{M}(\mathrm{r})$ component of the $\mathrm{C} 1 \mathrm{q}$ receptor. Immunity. 1995;3(4):485-93.

55. Allen LA, Aderem A. Molecular definition of distinct cytoskeletal structures involved in complementand Fc receptor-mediated phagocytosis in macrophages. The Journal of Experimental Medicine. 1996;184(2):627-37.

56. Spoerl D, Nigolian H, Czarnetzki C, Harr T. Reclassifying anaphylaxis to neuromuscular blocking agents based on the presumed patho-mechanism: IgE-mediated, pharmacological adverse reaction or "Innate Hypersensitivity"? Int J Mol Sci. 2017 Jun 7;18(6). pii: E1223. doi: 10.3390/ijms 18061223.

57. Borriello F, Iannone R, Marone G. Histamine Release from Mast Cells and Basophils. In: Hattori Y, Seifert R, editors. Histamine and Histamine Receptors in Health and Disease Handbook of Experimental Pharmacology, vol 241: Springer, Cham; 2017;241:121-139. 
58. McNeil BD, Pundir P, Meeker S, Han L, Undem BJ, Kulka M, et al. Identification of a mast-cell-specific receptor crucial for pseudo-allergic drug reactions. Nature. 2015;519(7542):237-41.

59. Soter NA. Mast cells in cutaneous inflammatory disorders. The Journal of Investigative Dermatology. 1983;80 Suppl:22s-5s.

60. Inturi S, Wang G, Chen F, Banda NK, Holers VM, Wu L, et al. Modulatory Role of Surface Coating of Superparamagnetic Iron Oxide Nanoworms in Complement Opsonization and Leukocyte Uptake. ACS Nano. 2015;9(11):10758-68.

61. Simberg D. Iron oxide nanoparticles and the mechanisms of immune recognition of nanomedicines. Nanomedicine (Lond). 2016;11(7):741-3.

62. Kuznetsova NR, Sevrin C, Lespineux D, Bovin NV, Vodovozova EL, Mészáros T, et al. Hemocompatibility of liposomes loaded with lipophilic prodrugs of methotrexate and melphalan in the lipid bilayer. Journal of Controlled Release. 2012;160(2):394-400.

63. Baranyi L, Szebeni J, Savay S, Bodo M, Basta M, Bentley TB, et al. Complement-dependent shock and tissue damage induced by intravenous injection of cholesterol-enriched liposomes in rats. Journal of Applied Research. 2003;3(3):221-231.

64. Merkel OM, Urbanics R, Bedőcs P, Rozsnyay Z, Rosivall L, Toth M, et al. In vitro and in vivo complement activation and related anaphylactic effects associated with polyethylenimine and polyethyleniminegrafted-poly (ethylene glycol) block copolymers. Biomaterials. 2011;32(21):4936-42. 